\title{
Extrapolative Modeling of International Trade using ARIMA Model: A Performance Comparison between India and China during COVID-19
}

\author{
Preeti Sharma \\ Amity Global Business School, Amity University, Noida - 201303, Uttar Pradesh, India; \\ sanskriti.112011@gmail.com
}

\begin{abstract}
A reshaping of the global supply chain is on the cards with companies searching for alternative supply choices, with the current instability in China and with some countries planning to pull their businesses out of China. India has already earned the reputation of being a responsible and trustworthy nation with efficient and participatory governance in these times of crisis. In the light of this scenery, the current study contrasts the success of Indian and Chinese foreign trade with the rest of the world.The merchandise trade and commercial service exports and imports from both countries with the rest of the world were obtained from the official WTO website to compare the output (deviation of actual from projected during COVID-19) of Indian and Chinese foreign trade with the rest of the world. The present research employs models of ARIMA using a three-step model creation process (i.e. model recognition, model estimation and diagnostic check). For the identification of the appropriate model ADF, PP Test, KPSS test and Auto-correlation function and partial auto-correlation function were used, approximate models were developed based on the defined p, d, q order and finally the diagnostic BoxLjung test was carried out. The results show that China has favorable merchandise trading conditions while India is in a stronger spot in the case of trade in services.
\end{abstract}

Keywords: ARIMA, Box-Ljung, India-China, International Trade, Merchandise Trade, Service Trade Forecast

JEL CODES: B22, C22, F12, F14, F17, F62

\section{Introduction}

India's response to the pandemic has so far been swift and prudent. Knowing the severity of an uncontrolled outbreak, the government has taken a timely decision on a full shutdown to carry out social distancing effectively. While the efforts to revive the domestic economy are in the right direction, we can also simultaneously begin to look at the effects of the crisis on international trade and investment and the lessons that India can learn to devise its future trade and investment strategy. During this turbulence period, international trade and investment are directly affected. According to the WTO, "in 2020, world trade is expected to decline between 13\% and 32\% as the COVID-19 pandemic disrupts normal economic activity and worldwide life." With this kind of prediction, in the near future, the prospects for global trade and investment look rather bleak. Economies diversified as regards export baskets will suffer less than those reliant on fewer products. Similarly, countries that depend heavily on the travel, hospitality and entertainment sectors will also be lagging behind other recovering countries due to significant disruptions in these sectors. US heavy reliance on China and India for pharmaceutical drugs has in 
these periods disrupted the US drug supply and resulted in shortages as a large number of Chinese drug factories shut down during the Corona virus outbreak. Although India is the world's largest supplier of generic medicines, it imports a significant portion of active pharmaceutical ingredients from China, thereby raising its dependency on China.

The current turmoil in China and with several countries preparing to pull their businesses out of China, a reshaping of the global supply chain is on the cards with corporations searching for alternative supply options. India has already gained a reputation in these times of crisis for being a responsible and trustworthy country with efficient and participatory governance. This needs to be balanced with an effort to improve the competitiveness of India in areas with export potential that can become essential components of the global value chain. It needs to be balanced by an effort to improve India's competitiveness in areas with export potential which can become integral components of the global value chain.

Considering all of the above showing potential for India as China is no longer a trusted venue on the world market now we would like to make a comparison of merchandise and service trade in the COVID-19 era to understand India's increased share in this time as compared to China. The analysis is broken down into six parts. First sections discuss the theoretical context to the subject at hand. The second section discusses related literature on the subject. The third section provides the detail of methodology and describes the data used for analysis. The fourth sections discuss the validity of research along with the empirical findings and explanations thereof. Section five discusses the threat to validity of the current work. Finally, the last section identifies the outcome of the analysis undertaken, its implications and future research directions.

\section{Review of Related Literature}

This section presents an extensive review of literature on the studies available on trade performances and comparison thereof. Due to the outbreak of COVID-19, the international trade of almost all the economies is hurt badly. Different scholars have conducted different studies to evaluate the impact of COVID-19 on international trade of countries (Pal, 2020; Vidya \& Prabheesh, 2020; Bell, Roberton, \& Hunter, 2004). Dhinakaran, D. D. P., \& Kesavan, N. (2020) have studies the exports and imports stagnation in India during COVID-19. Baldwin, R., \& Tomiura, E. (2020) have studied the negative impact of COVID-19 on international demand of tradable goods and services and future of trade in G7 plus China. Mandal, M., \& Mandal, S. (2020) compared the COVID19 data from India was compared with China and rest of the world. Alon, I. (2020) studies the impact of COVID19 on international business and globalization.

Before COVID-19 also several studies were conducted to compare the international trade and economic scenarios of the India and China. (Khan \& Ahmad, 2017) analyzed the export pattern and competitiveness of India-China in Global and Bilateral Market. This study reviews the competitiveness of trade between India and China in normal in general economic situations. Some studies also compare the route and development of FDI in both the economies. By emerging Chinese and Indian multinationals, (Pradhan, 2017) dealt with the root and development of Outward Foreign Direct Investment (OFDI) and investigates the locational determinants of such investment.

(Ahmad, Kunroo, \& Sofi, 2018) studied the short and long-term trade pattern of India and China's using the Revealed Comparative Advantage (RCA) and bilateral RCA, this study specifically attempts to identify export patterns and specialization areas of the economies under investigation. Scholars have also compared the value added in the developing and developed economies. Zhao, Y. et al. (2018) compared domestic value added differences between China and the US, Japan, Korea, and India based on generalized LMDI taking value-added coefficient effect, effect of input-output structure, effect of domestic scale and effect of international scale.

From the conclusive summary of related literature a wide gap can be seen for study on offered topic of comparison of international trade of India and China with rest of the world. The gap can be used to create dynamic autoregressive models of merchandise and service imports and exports of both the countries. Therefore present study intends to make some conclusive contribution on trade performance comparison by both the countries in current COVID-19 context. 


\section{Data Descriptive and Analytical Framework}

To compare the performance (deviation of actual from estimated during COVID-19) of International Trade of India and China with rest of the world, the merchandise trade and commercial service exports and imports of both the countries with rest of the world have been obtained. The data have been taken on monthly basis starting from January 2013 to April 2020. The data with respect of commercial service exports and imports of China could be obtained from January 2015, so the study extrapolates China's commercial service imports and exports on the basis of available data. The data has been sourced from official website of World Trade Organization. The data from 2013 to 2019 has been used for developing the predictive model using auto regressive integrated moving average model and remaining four month data (January 2020 to April 2020) has been used to compare the performance by calculation of deviation between estimated and actual trade of the countries.

\subsection{Econometrics Model Building}

Box-Jenkins method or ARIMA (Auto Regressive Integrated Moving Average) are popular models when the time series forecast is to be done on the basis of its own past values, its own lags and lagged forecast errors. The econometric modeling through ARIMA includes the following steps:

\section{Step 1: Identification of Suitable Model}

The model identification (to find the order $\mathbf{p}, \mathbf{d}, \mathbf{q}$ ) is the first step in constructing ARIMA model.

$p$ is the number of autoregressive terms,

$d$ is the number of differencing done to make series stationary $q$ is the number of lagged forecast errors in the prediction equation

As per George P. Box and Gwilym Jenkins, these models work on both stationary and non-stationary (made stationary after differencing) time series. So the first stage in ARIMA model building involves to check the stationarity of times series.

There are a number of tests available to check the stationarity of time series data but for current study uses the Augmented Dickey-Fuller (ADF) and the PhilipsPerron (PP) test to check the stationarity of series. Both the Augmented Dickey-Fuller (ADF) and the Philips-Perron
(PP) are sometimes unable to reject the null hypothesis about non stationarity so just to be more confirm on results the study also employs the Kwiatkowaski-PhilipsSchmidt-Shin (KPSS) unit root test. This practice of joint use of unit root (ADF and PP) and stationarity (KPSS) tests is known as confirmatory data analysis (Brooks, 2002). Here it is to be noted first two tests have null hypothesis about non-stationarity but KPSS test has null hypothesis about stationarity of the series. Trend plots of taken series also have been created to check the stationarity in the series. The number of differencing required to make the series stationary will give the value of $d$.

\section{Step 2: Estimation through Model}

The second stage in identification involves finding suitable values of $\mathrm{p}$ in $\mathrm{AR}$ and $\mathrm{q}$ in MA terms. To find the lags of $\mathrm{AR}$ and MA the plots of correlogram (Auto Correlation Function) and partial correlogram (Partial autocorrelation function) of stationary series have been created. The plots propose the values of $\mathrm{p}$ and $\mathrm{q}$ on the basis of which models of prediction for taken eight series have been done.

\section{Step 3: Diagnostic checking of Models}

For diagnostic checking of forecast models, error (residuals) have been plotted, to investigate the correlation between successive forecast errors (residuals), correlogram (ACF) and partial correlogram (PACF) have been created and to check whether the residuals are white noise or not Box-L jung test has been conducted.

\section{Empirical Results}

The Figure 1 to Figure 1.8 are the trend plots of China's merchandise exports, India's Merchandise exports, China's merchandise imports, India's merchandise imports, China's commercial service exports, India's commercial service exports, China's commercial service imports and India's commercial service imports respectively (Figures attached in appendices). Table 1 and Table 2 shows the results of Augmented Dickey full unit root test, Phillips perron test and Kwiatkowaski-Philips- Schmidt-Shin (KPSS) unit root test. Table 1 presents the unit root test results at level while Table 2 shows the results at first differencing. Both the figures and tables confirm 
the non-stationarity of our seven series at level and stationarity at first differencing. Only the time series of China's merchandise exports is stationary at level (As per test values). So order $(\mathrm{d}=\mathbf{0})$ can be accepted for China's merchandise exports. While order $(\mathrm{d}=1)$ can be taken for remaining series.

On observing the results of Phillips perron test it can be noticed that the null hypothesis about non- stationarity of series is rejected even at level in case of India's merchandise trade, China's merchandise imports, China's commercial service exports, China's commercial service imports and India's commercial service imports, but other two test confirm about non-stationarity at level so the series have been differenced once to make them stationary.

Table 1. Stationarity test: series at level

\begin{tabular}{|l|c|c|c|c|c|c|}
\hline \multirow{2}{*}{ Variable } & \multicolumn{2}{|c|}{ ADF } & \multicolumn{2}{c|}{ PP test } & \multicolumn{2}{c|}{ KPSS } \\
\cline { 2 - 7 } & $\begin{array}{c}\text { test } \\
\text { statistic }\end{array}$ & p- value & Z-alpha & p- value & $\begin{array}{c}\text { test } \\
\text { statistic }\end{array}$ & p- value \\
\hline $\begin{array}{l}\text { China's Total merchandise exports } \\
\text { (Million US dollar) }\end{array}$ & -3.71 & 0.03 & -48.50 & 0.01 & 0.63 & 0.19 \\
\hline $\begin{array}{l}\text { India's Total merchandise exports } \\
\text { (Million US dollar) }\end{array}$ & -1.79 & 0.66 & -38.76 & 0.01 & 0.45 & 0.06 \\
\hline $\begin{array}{l}\text { China's Total merchandise imports } \\
\text { (Million US dollar) }\end{array}$ & -1.857 & 0.63 & -39.47 & 0.01 & 0.66 & 0.018 \\
\hline $\begin{array}{l}\text { India's Total merchandise imports } \\
\text { (Million US dollar) }\end{array}$ & -2.42 & 0.40 & -17.53 & 0.10 & 0.57 & 0.03 \\
\hline $\begin{array}{l}\text { China's Commercial services exports } \\
\text { (Million US dollar) }\end{array}$ & -2.48 & 0.38 & -46.86 & 0.01 & 1.27 & 0.01 \\
\hline $\begin{array}{l}\text { India’s Commercial services exports } \\
\text { (Million US dollar) }\end{array}$ & -1.51 & 0.78 & -16.22 & 0.16 & 1.70 & 0.01 \\
\hline $\begin{array}{l}\text { China's Commercial services imports } \\
\text { (Million US dollar) }\end{array}$ & -3.47 & 0.05 & -41.60 & 0.01 & 1.08 & 0.01 \\
\hline $\begin{array}{l}\text { Indiass Commercial services imports } \\
\text { (Million US dollar) }\end{array}$ & -2.37 & 0.42 & -25.50 & 0.02 & 1.83 & 0.01 \\
\hline
\end{tabular}

Source: Author's Calculation 


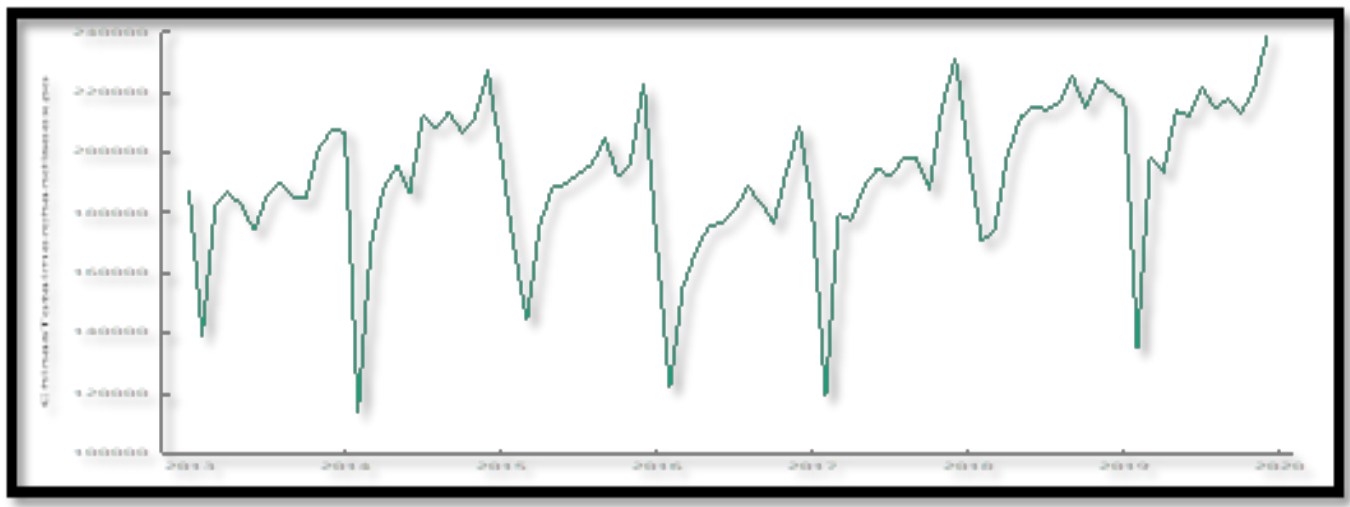

Figure 1.1 China's merchandise export.

Source: Author's Formation based on data

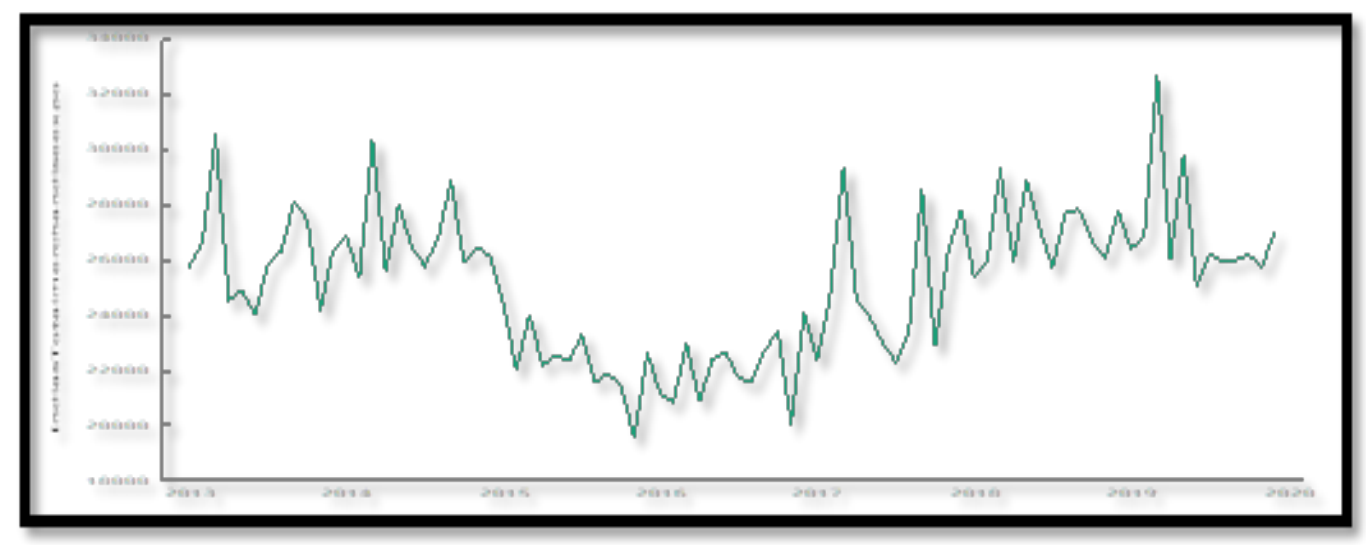

Figure 1.2 India's merchandise export.

Source: Author's Formation based on data

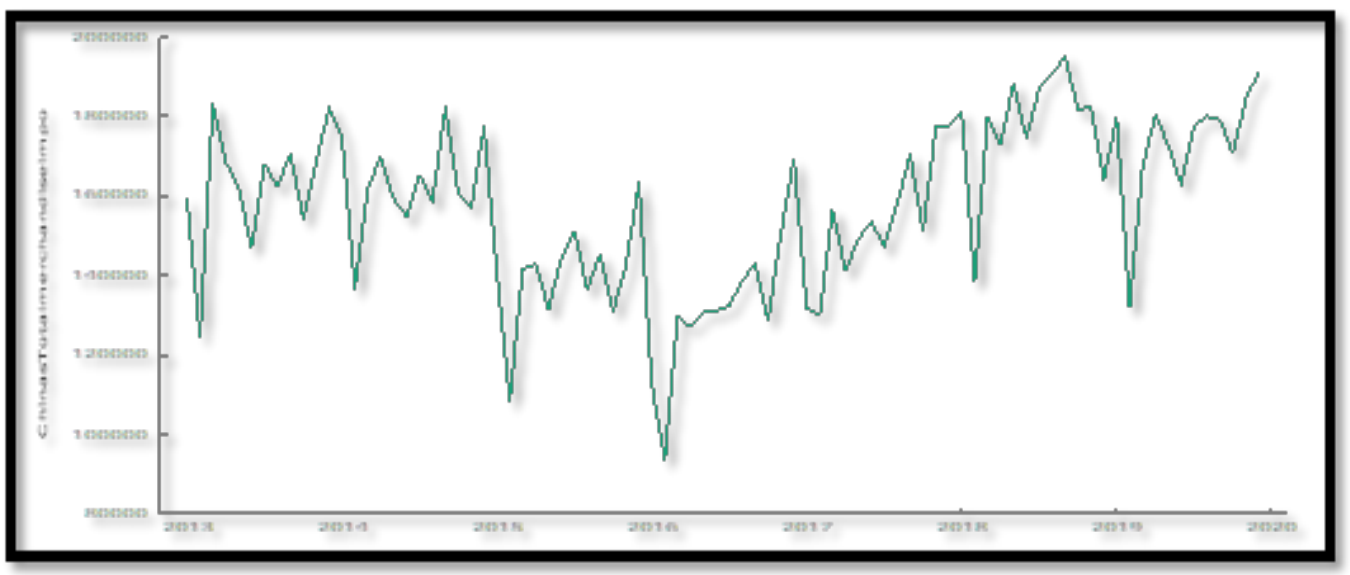

Figure 1.3 China's Merchandise imports.

Source: Author's Formation based on data 


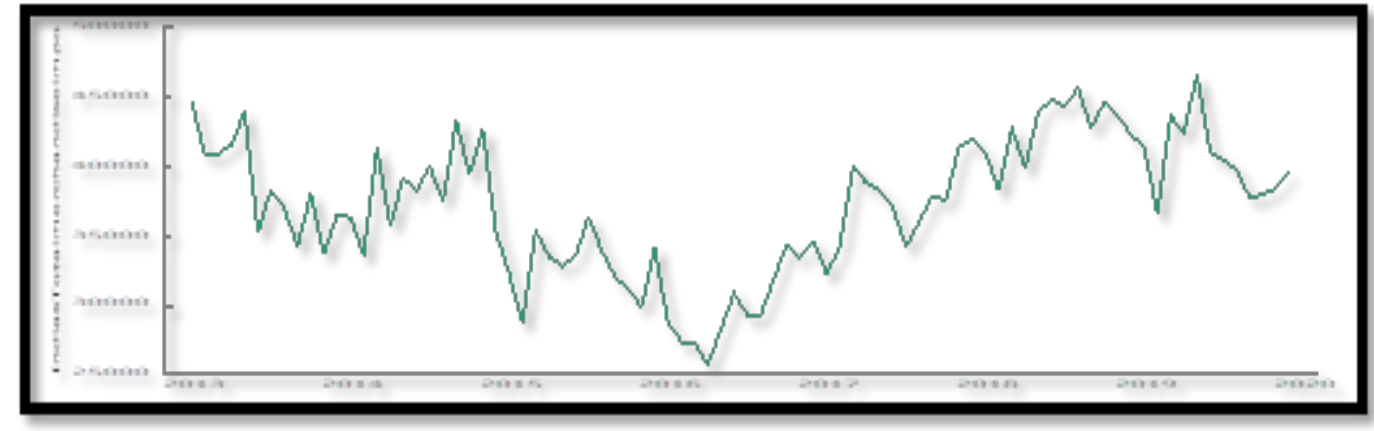

Figure 1.4 India's merchandise imports..

Source: Author's Formation based on data

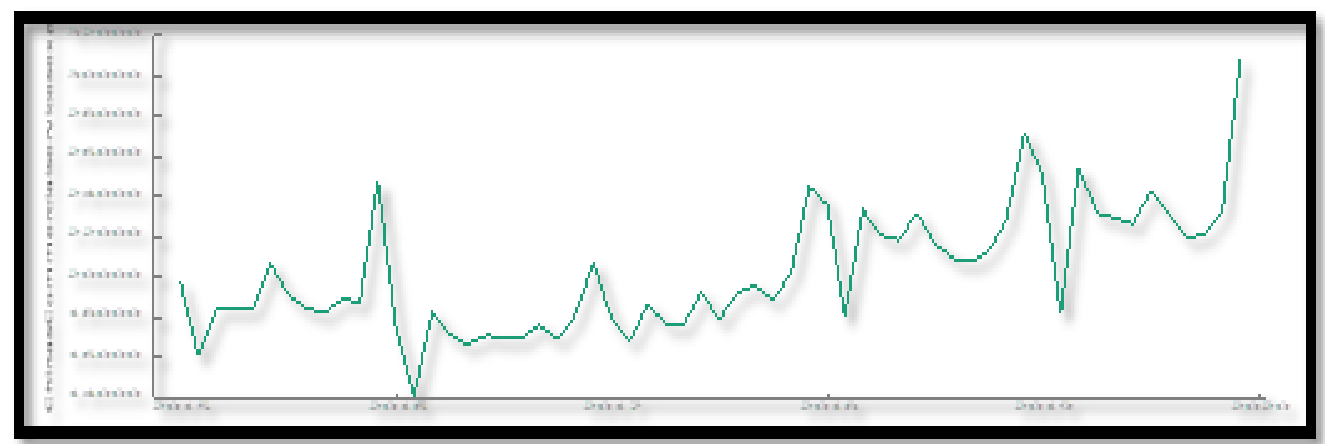

Figure 1.5 China's service exports.

Source: Author's Formation based on data

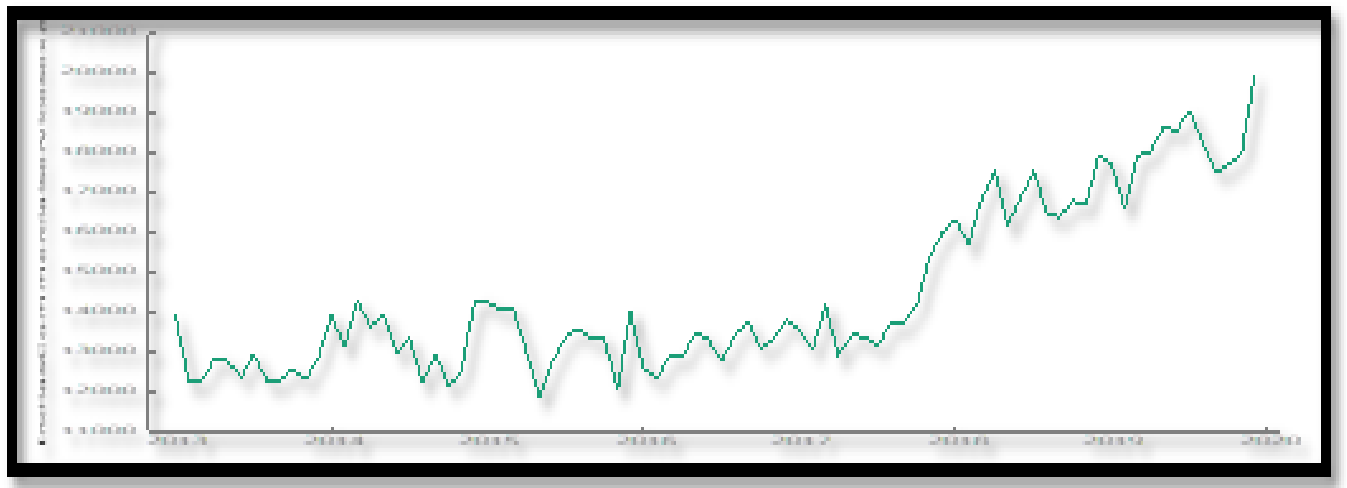

Figure 1.6 India's service exports.

Source: Author's Formation based on data 


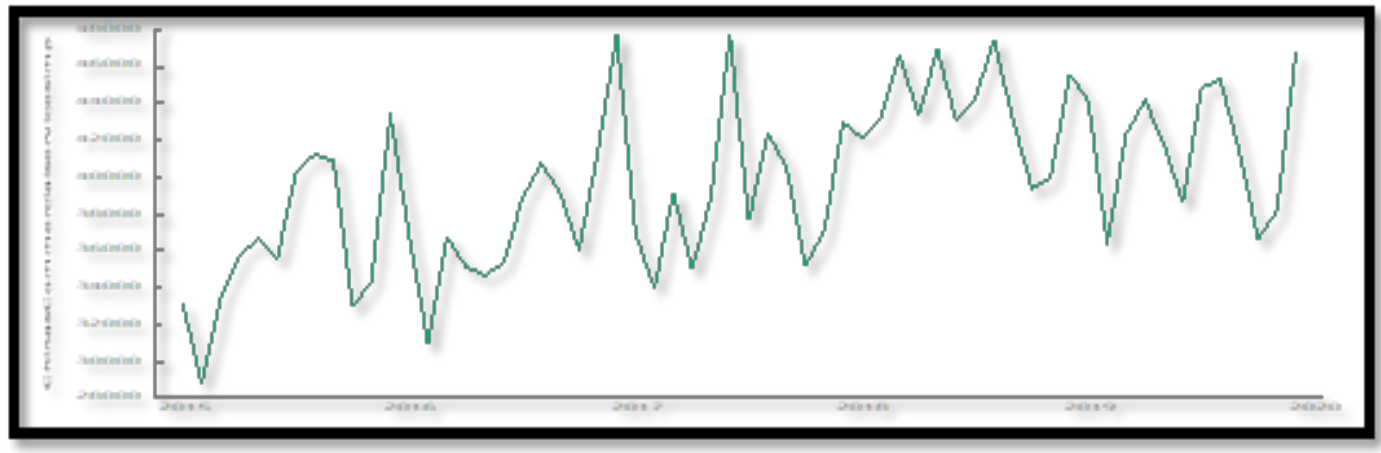

Figure 1.7 China's service imports.

Source: Author's Formation based on data

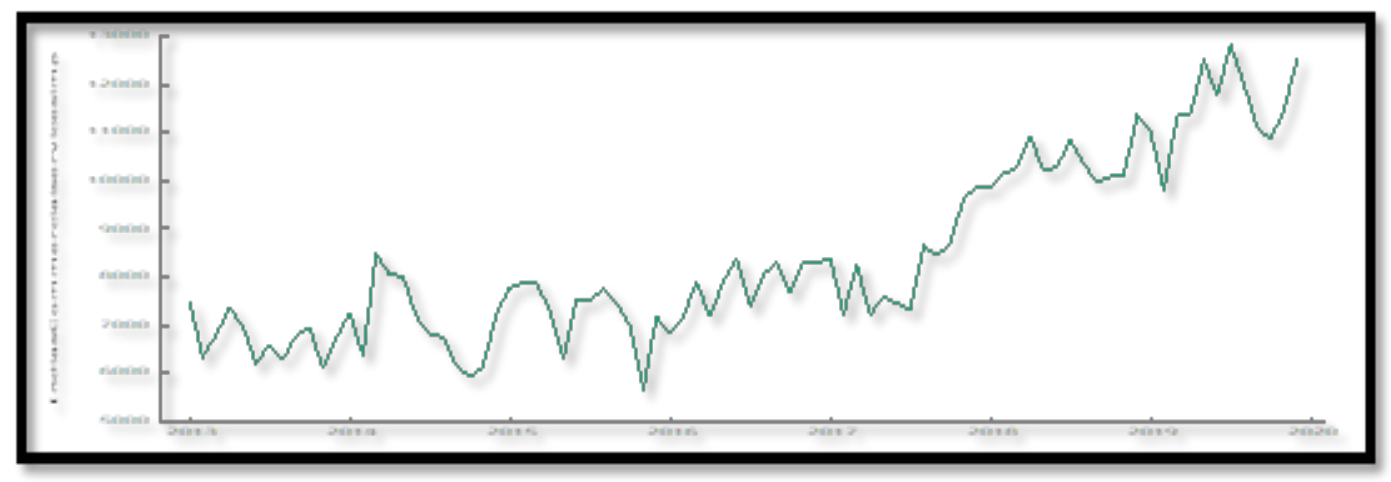

Figure 1.8 India's service imports.

Source: Author's Formation based on data

Table 2. Stationarity test at first difference

\begin{tabular}{|l|l|l|l|l|l|l|}
\hline \multirow{2}{*}{ Variable } & \multicolumn{2}{l}{ ADF } & \multicolumn{2}{l|}{ PP test } & \multicolumn{2}{l|}{ KPSS } \\
\cline { 2 - 7 } & test statistic & p-value & Z-alpha & p-value & test statistic & p-value \\
\hline $\begin{array}{l}\text { India's Total merchandise } \\
\text { exports (Million US dollar) }\end{array}$ & -7.34 & 0.01 & -116.92 & 0.01 & 0.051 & 0.1 \\
\hline $\begin{array}{l}\text { China's Total merchandise } \\
\text { imports (Million US dollar) }\end{array}$ & -5.51 & 0.01 & -96.69 & 0.01 & 0.089 & 0.1 \\
\hline
\end{tabular}


Table 2 Continued

\begin{tabular}{|l|l|l|l|l|l|l|}
\hline $\begin{array}{l}\text { India's Total merchandise } \\
\text { imports (Million US dollar) }\end{array}$ & -5.06 & 0.01 & -114.92 & 0.01 & 0.145 & 0.1 \\
\hline $\begin{array}{l}\text { China's Commercial services } \\
\text { exports (Million US dollar) }\end{array}$ & -5.90 & 0.01 & -62.52 & 0.01 & 0.188 & 0.1 \\
\hline $\begin{array}{l}\text { India's Commercial services } \\
\text { exports (Million US dollar) }\end{array}$ & -5.93 & 0.01 & -99.53 & 0.01 & 0.1 \\
\hline $\begin{array}{l}\text { China's Commercial services } \\
\text { imports (Million US dollar) }\end{array}$ & -5.83 & 0.01 & 0.01 & -101.98 & 0.01 & 0.01 \\
\hline $\begin{array}{l}\text { India's Commercial services } \\
\text { imports (Million US dollar) }\end{array}$ & -5.67 & & & 0.19 & 0.1 \\
\hline
\end{tabular}

Source: Author's Calculation

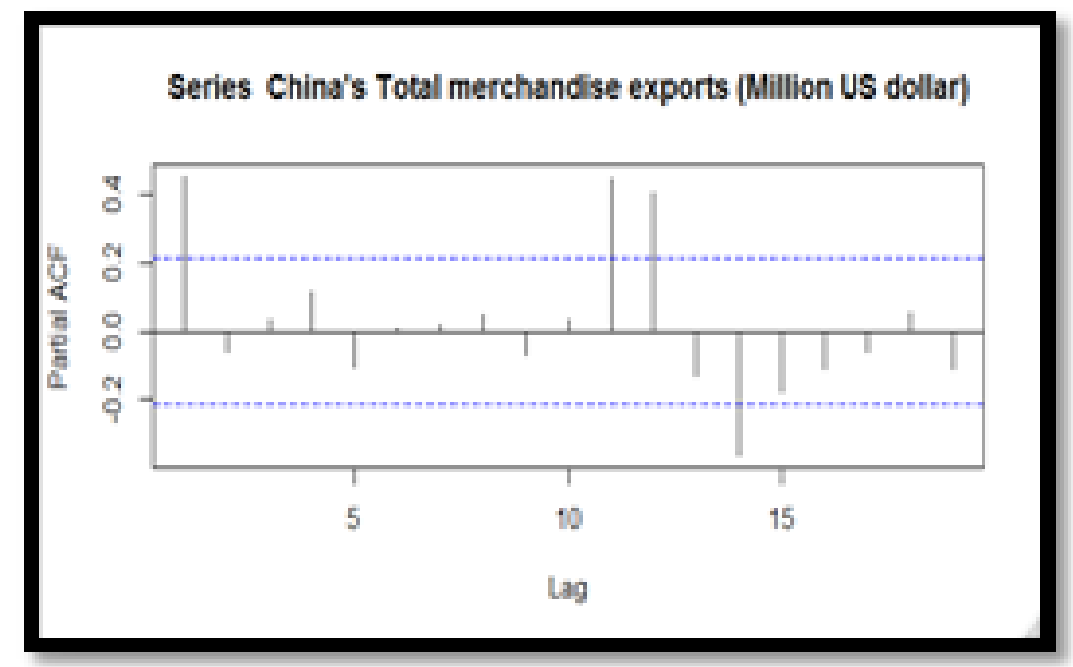

Figure 2.1

Figures 2.1 to 2.16 presents the correlogram (ACF) and partial correlogram (PACF) plots of differenced times series for lags 1 to 20. As per the results of ACF and PACF plots the $\mathrm{p}$ and $\mathrm{q}$ order for ARIMA models have been selected.
Table 3 show different ARIMA models selected for different time series'. So after identifying different models the estimation has been done to find coefficient of ARIMA models. 


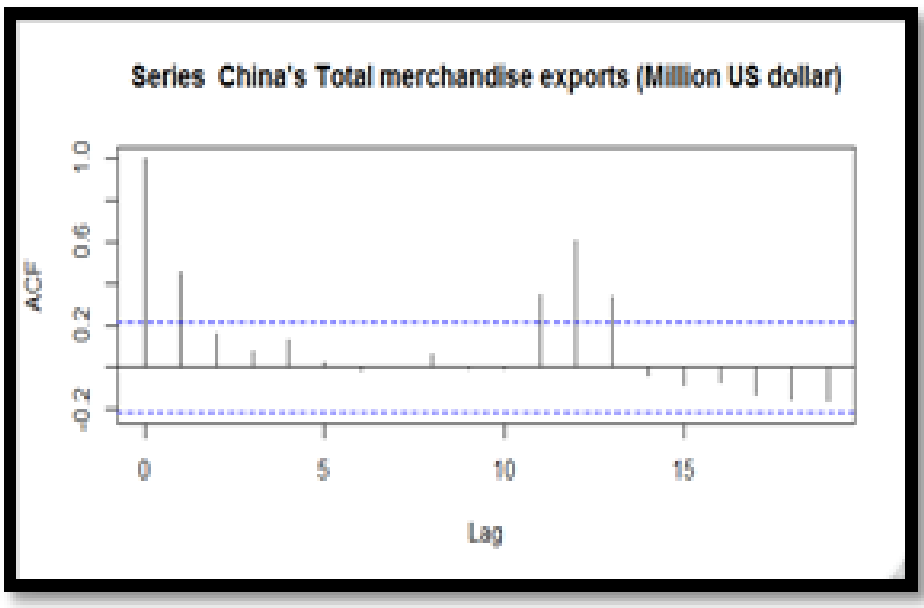

Figure 2.2

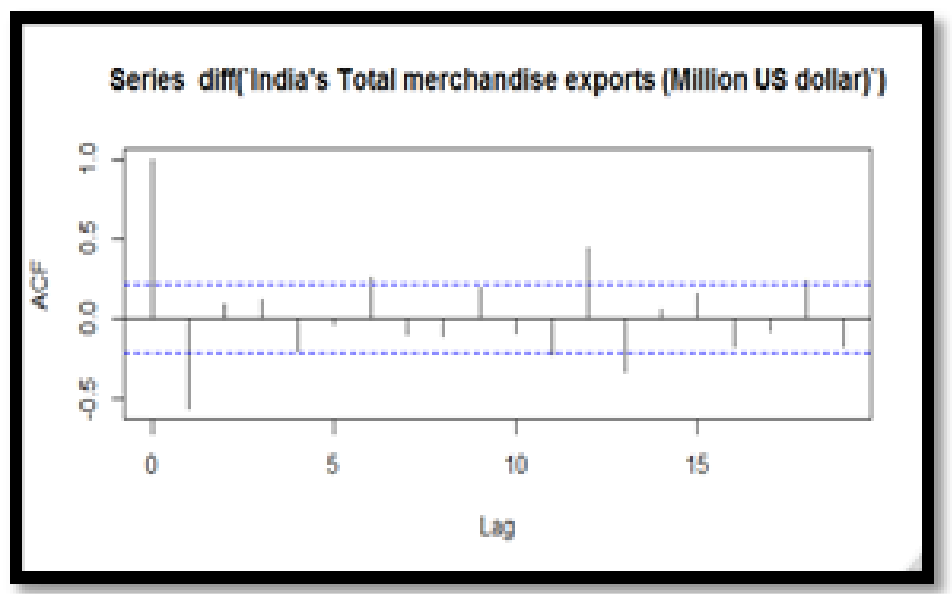

Figure 2.3

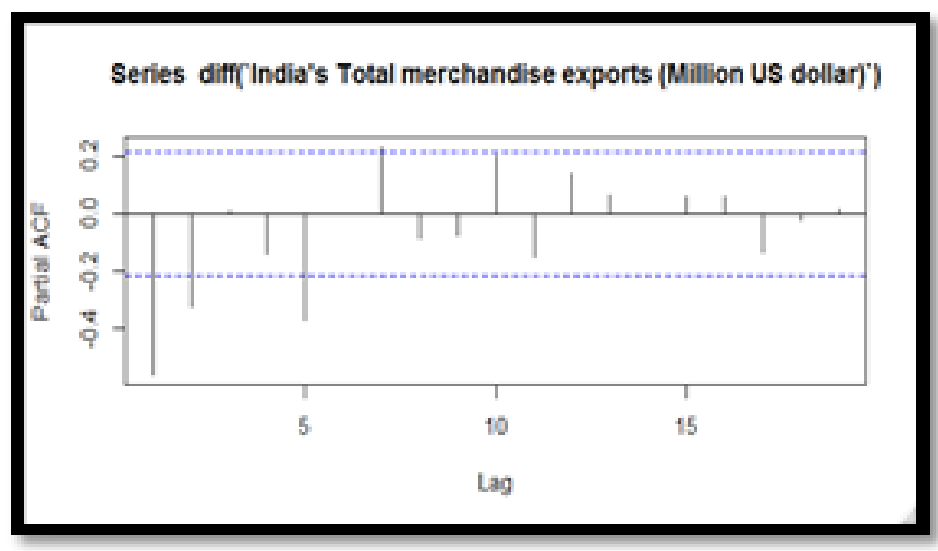

Figure 2.4 


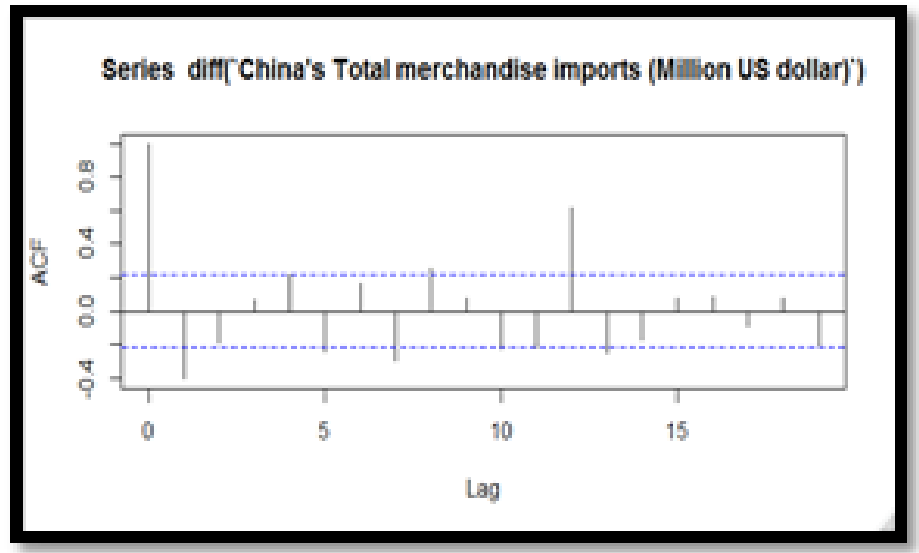

Figure 2.5

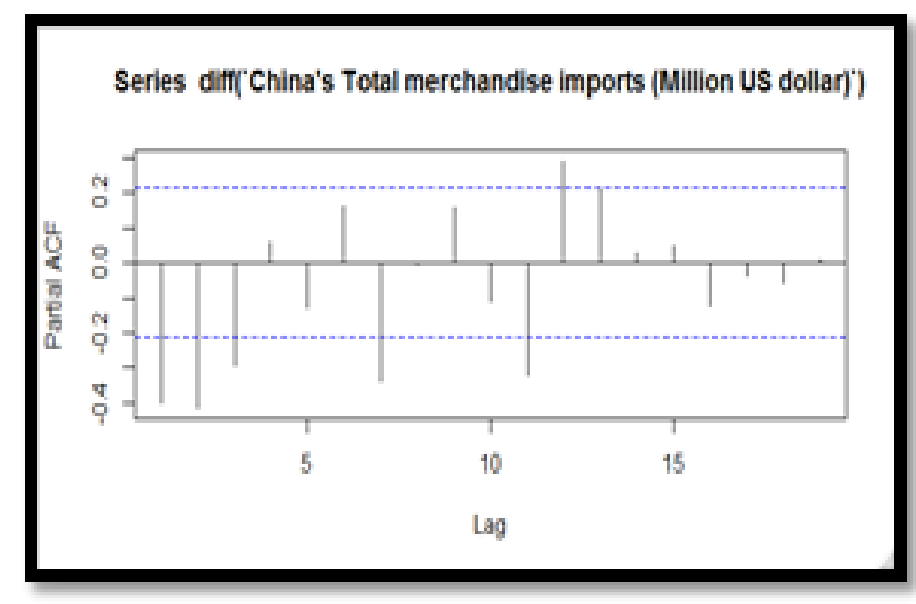

Figure 2.6

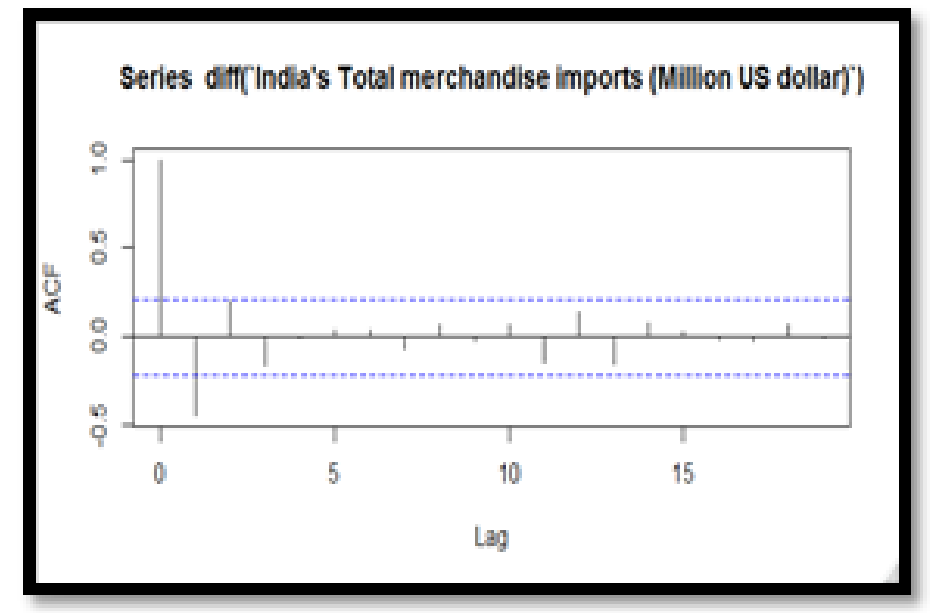

Figure 2.7 


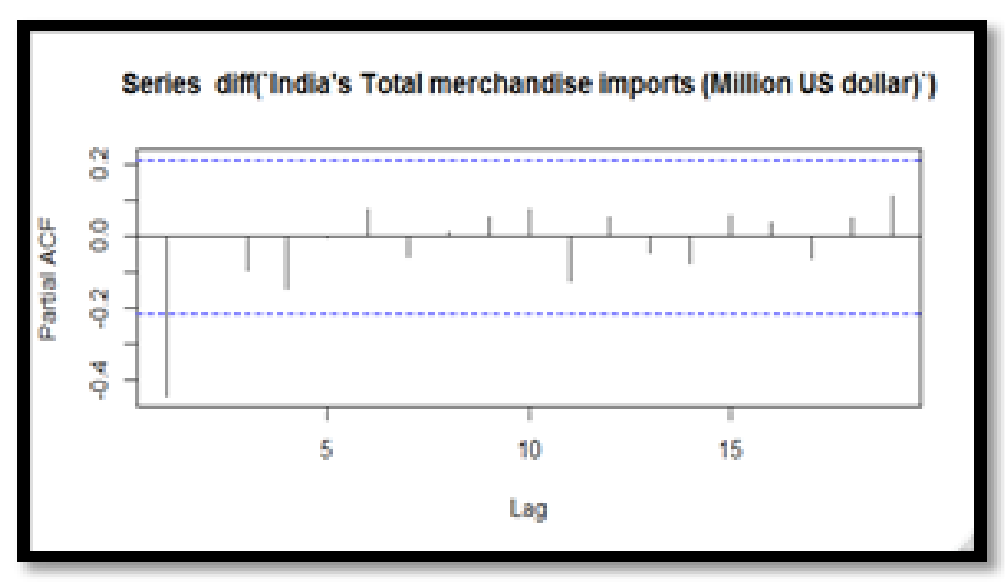

Figure 2.8

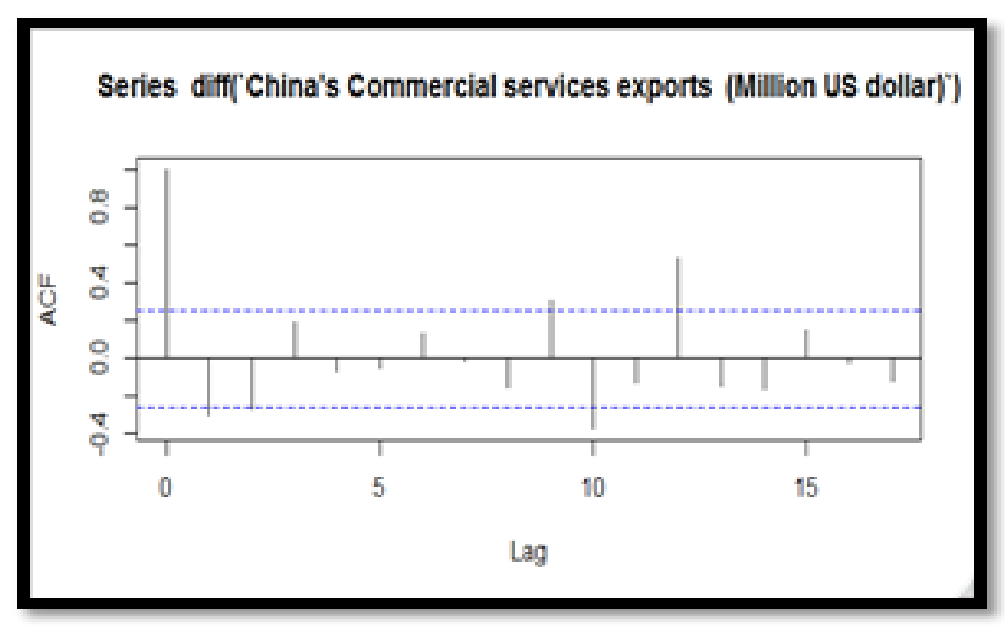

Figure 2.9

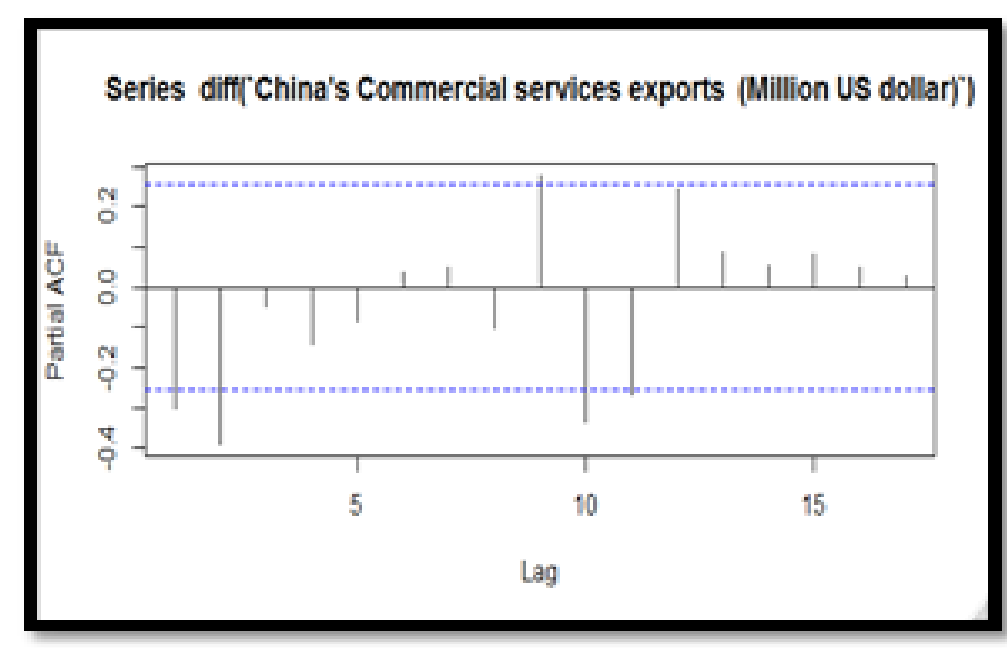

Figure 2.10 


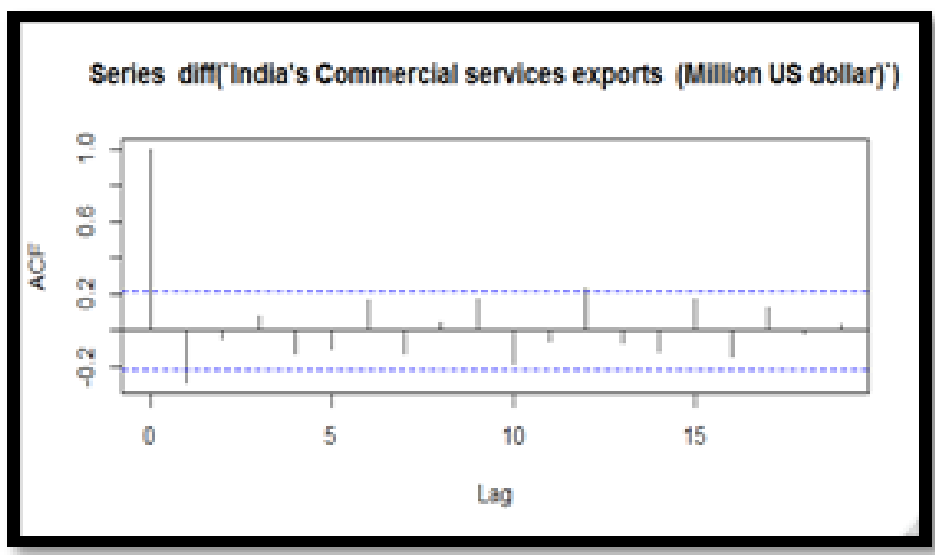

Figure 2.11

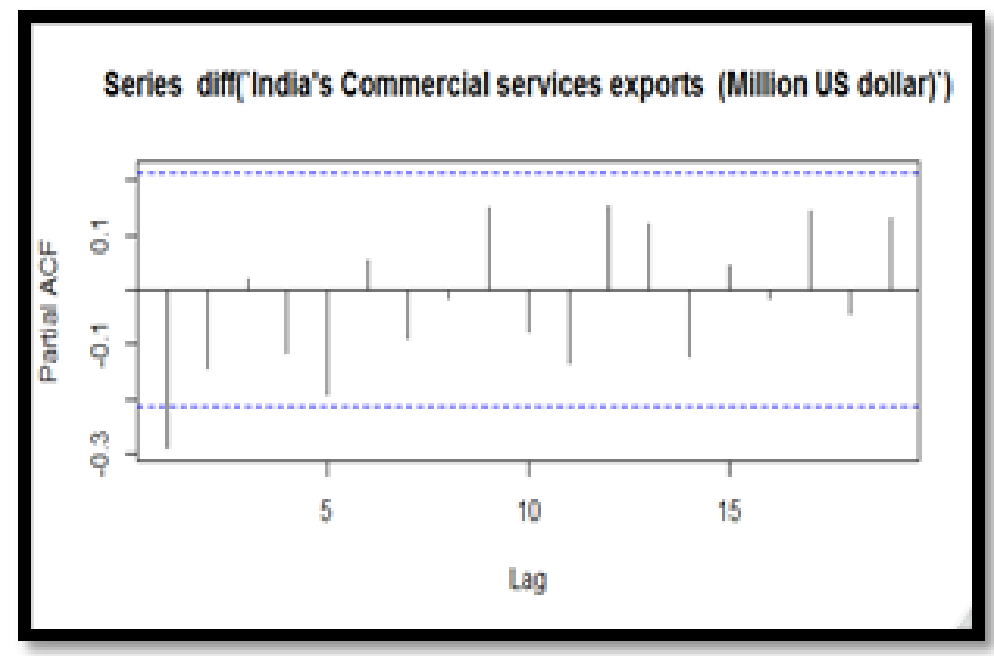

Figure 2.12

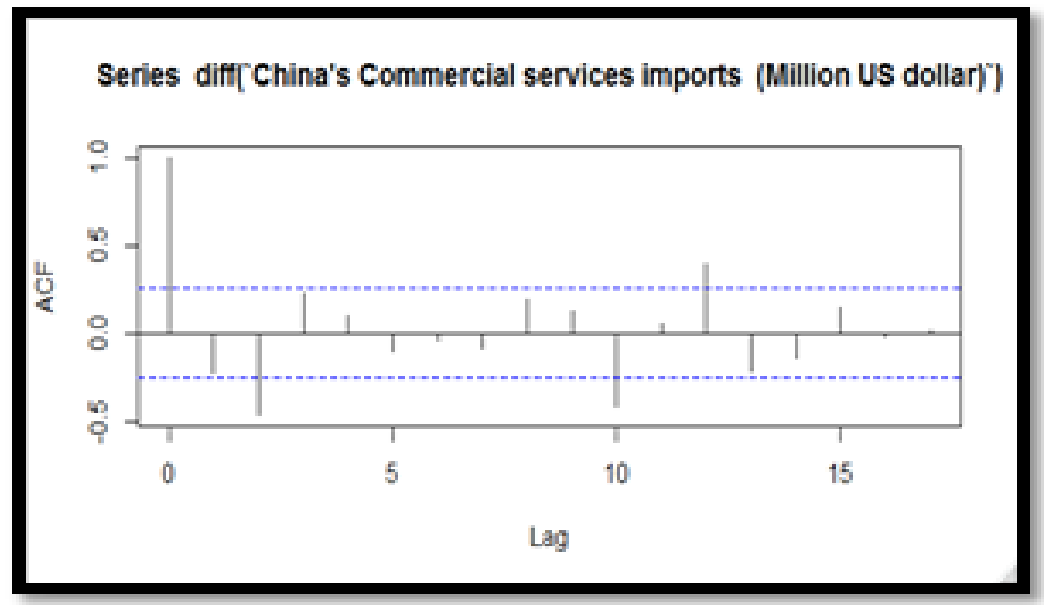

Figure 2.13 


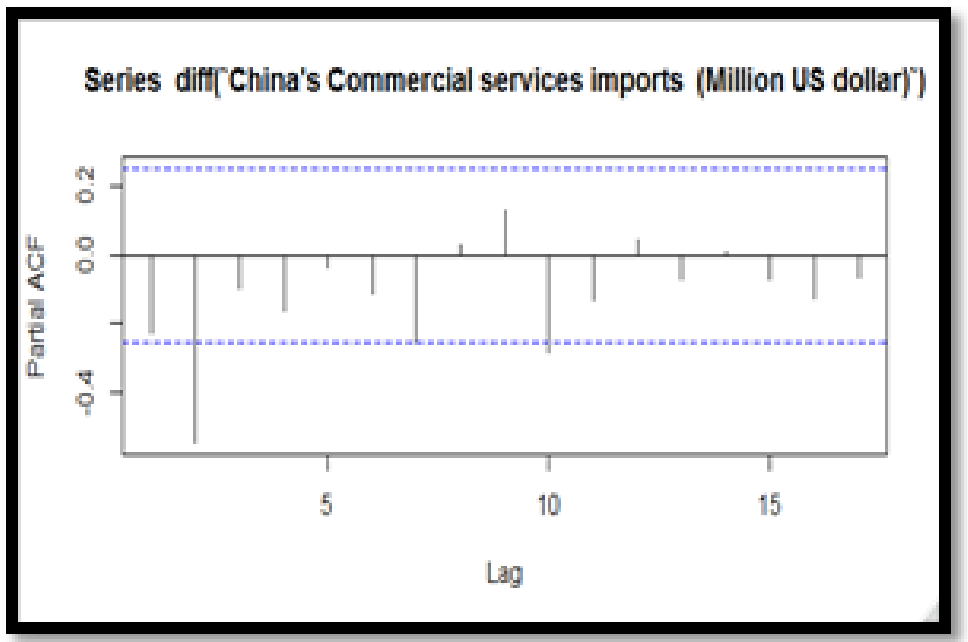

Figure 2.14

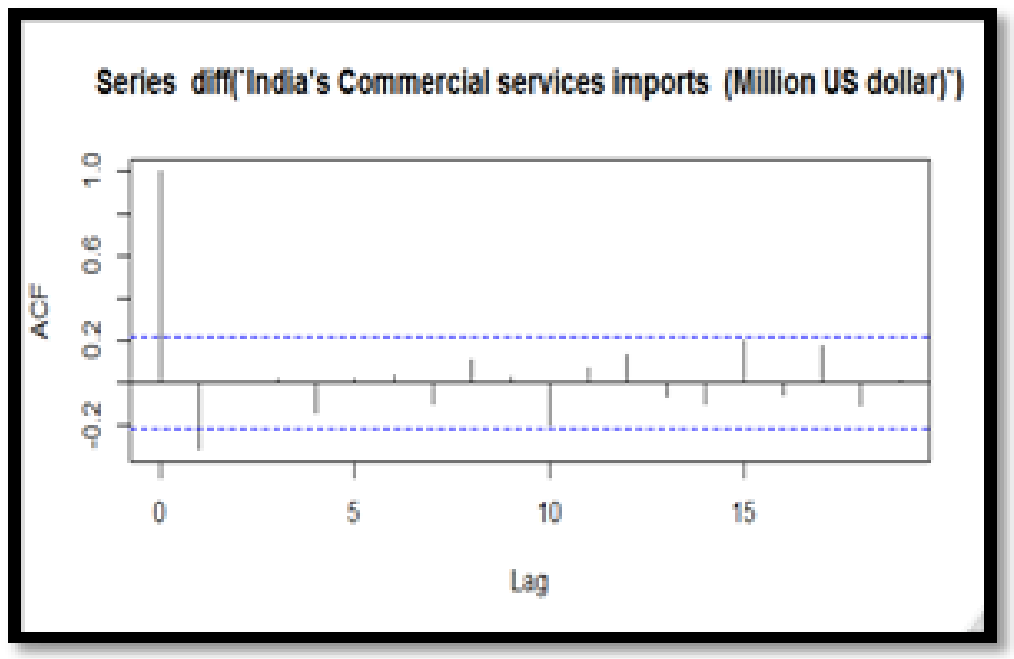

Figure 2.15

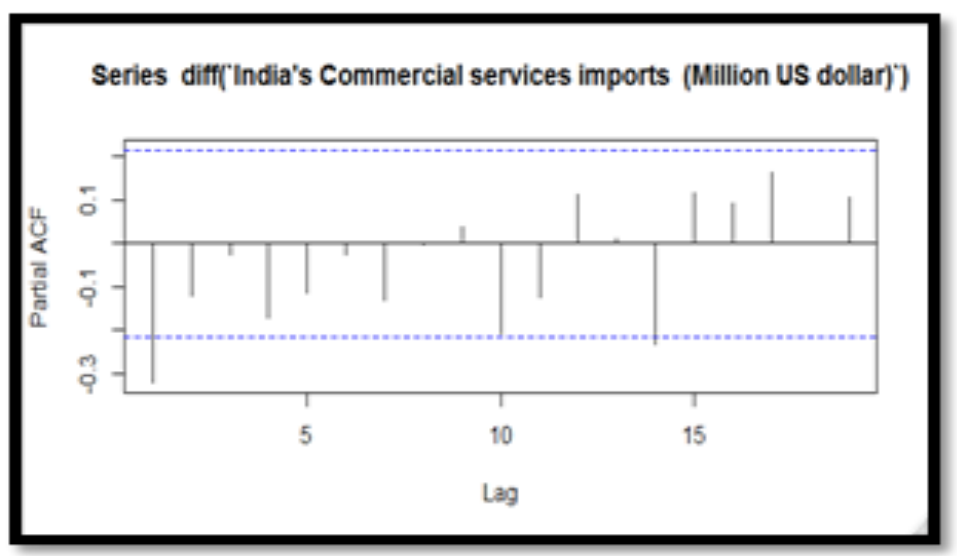

Figure 2.16 
Table 4 presents the coefficients of ARIMA models applied after identification of models. All the coefficients are significant at $1 \%$ level of confidence except China's merchandise imports (significant at 5\% level).

Table 3. ARIMA models for different time series'

\begin{tabular}{|l|l|}
\hline Variable & ARIMA MODEL \\
\hline China's Total merchandise exports (Million US dollar) & ARIMA $(0,1,2)$ \\
\hline India's Total merchandise exports (Million US dollar) & ARIMA $(2,1,2)$ \\
\hline China's Total merchandise imports (Million US dollar) & ARIMA $(3,1,2)$ \\
\hline India’s Total merchandise imports (Million US dollar) & ARIMA $(1,1,0)$ \\
\hline China's Commercial services exports (Million US dollar) & $(0,1,1)$ with drift \\
\hline India’s Commercial services exports (Million US dollar) & $(0,1,1)$ with drift \\
\hline China's Commercial services imports (Million US dollar) & $(0,1,0)$ \\
\hline India’s Commercial services imports (Million US dollar) & $(0,1,1)$ \\
\hline
\end{tabular}

Source: Author's Calculation

Table 4. Coefficients of AR and MA terms (ARIMA models)

\begin{tabular}{|c|c|c|c|c|c|}
\hline & & Estimate & Std. Error & $\mathrm{z}$ value & $\operatorname{Pr}(>|z|)$ \\
\hline \multirow{2}{*}{$\begin{array}{l}\text { China's Total merchandise exports } \\
\text { (Million US dollar) }\end{array}$} & mal & -0.537 & 0.096 & -5.616 & $1.96 \mathrm{e}-08^{\star * *}$ \\
\hline & $\mathrm{ma} 2$ & -0.321 & 0.092 & -3.474 & $0.0005137^{* * *}$ \\
\hline \multirow{4}{*}{$\begin{array}{l}\text { India's Total merchandise exports } \\
\text { (Million US dollar) }\end{array}$} & ar1 & -0.966 & 0.091 & -10.673 & $<2.2 \mathrm{e}-16^{* * *}$ \\
\hline & ar2 & -0.910 & 0.097 & -9.379 & $<2.2 \mathrm{e}-16^{* * *}$ \\
\hline & mal & 0.798 & 0.146 & 5.482 & $4.211 \mathrm{e}-08^{\star * *}$ \\
\hline & $\mathrm{ma} 2$ & 0.800 & 0.144 & 5.546 & $2.922 \mathrm{e}-08^{* * *}$ \\
\hline
\end{tabular}


Table 4 Continued

\begin{tabular}{|c|c|c|c|c|c|}
\hline \multirow{5}{*}{$\begin{array}{l}\text { China's Total merchandise imports } \\
\text { (Million US dollar) }\end{array}$} & ar1 & -1.279 & 0.187 & -6.854 & $7.193 \mathrm{e}-12^{\star * *}$ \\
\hline & ar2 & -0.830 & 0.275 & -3.019 & $0.002540^{\star \star}$ \\
\hline & ar3 & -0.532 & 0.123 & -4.340 & $1.423 \mathrm{e}-05^{\star * *}$ \\
\hline & mal & 0.712 & 0.229 & 3.108 & $0.001884^{\star *}$ \\
\hline & ma2 & -0.156 & 0.235 & -0.664 & 0.507 \\
\hline $\begin{array}{l}\text { India’s Total merchandise imports } \\
\text { (Million US dollar) }\end{array}$ & ar1 & -0.450 & 0.098 & -4.580 & $4.642 \mathrm{e}-06^{* * *}$ \\
\hline $\begin{array}{l}\text { China's Commercial services exports } \\
\text { (Million US dollar) }\end{array}$ & ma1 & -0.753 & 0.079 & -9.480 & $<2.2 \mathrm{e}-16^{* * *}$ \\
\hline $\begin{array}{l}\text { India’s Commercial services exports } \\
\text { (Million US dollar) }\end{array}$ & ma1 & -0.398 & 0.116 & -3.435 & $0.0005923^{* * *}$ \\
\hline $\begin{array}{l}\text { India’s Commercial services imports } \\
\text { (Million US dollar) }\end{array}$ & mal & -0.395 & 0.114 & -3.470 & $0.0005199^{* * *}$ \\
\hline
\end{tabular}

Source: Author's Calculation

Table 5. Box-Ljungtest (Diagnostic checking)

\begin{tabular}{|l|l|l|}
\hline Variable & X-squared & p-value \\
\hline China's Total merchandise exports (Million US dollar) & 0.053 & 0.819 \\
\hline India’s Total merchandise exports (Million US dollar) & 0.016 & 0.898 \\
\hline China's Total merchandise imports (Million US dollar) & 0.305 & 0.581 \\
\hline India’s Total merchandise imports (Million US dollar) & 1.242 & 0.265 \\
\hline China’s Commercial services exports (Million US dollar) & 0.078 & 0.780 \\
\hline India’s Commercial services exports (Million US dollar) & 3.685 & 0.055 \\
\hline China’s Commercial services imports (Million US dollar) & 9.180 & 0.002 \\
\hline India’s Commercial services imports (Million US dollar) & 3.520 & 0.061 \\
\hline
\end{tabular}

Source: Author's Calculation 
Table 5 shows the results of Ljung-Box test statistic for examining the null hypothesis of independence in a given time series which is accepted in case of all time series'. So we can conclude that the ARIMA models of series' are best fit.
Table 6 presents the predicted values of merchandise and service trade (exports and imports) of both the countries with rest of the world. Further we see the comparison between estimated and actual and the deviation of actual from estimated has been calculation

Table 6. Estimated vs. actual

\begin{tabular}{|c|c|c|c|c|c|}
\hline & Period & Estimated & Actual & Deviation & \% deviation \\
\hline \multirow{4}{*}{$\begin{array}{l}\text { China's Total merchandise } \\
\text { exports (Million US dollar) }\end{array}$} & Jan-20 & 225424.6 & & & \\
\hline & Feb-20 & 218937.7 & 292449 & -73511.3 & -33.58 \\
\hline & Mar-20 & 218842.3 & 185179 & 33663.3 & 15.38 \\
\hline & Apr-20 & 219504.1 & 200234 & 19270.1 & 8.79 \\
\hline \multirow{4}{*}{$\begin{array}{l}\text { India's Total merchandise } \\
\text { exports (Million US dollar) }\end{array}$} & Jan-20 & 25972.13 & 25841 & 131.13 & 0.50 \\
\hline & Feb-20 & 26088.32 & 27654 & -1565.68 & -6.00 \\
\hline & Mar-20 & 26984.4 & 21406 & 5578.4 & 20.67 \\
\hline & Apr-20 & 25997.51 & 10356 & 15641.51 & 60.17 \\
\hline \multirow{4}{*}{$\begin{array}{l}\text { China's Total merchandise } \\
\text { imports (Million US dollar) }\end{array}$} & Jan-20 & 187214.8 & & & 0 \\
\hline & Feb-20 & 176760.9 & 299544 & -122783.1 & -69.46 \\
\hline & Mar-20 & 189789.1 & 165299 & 24490.1 & 12.90 \\
\hline & Apr-20 & 183988.8 & 154901 & 29087.8 & 15.81 \\
\hline \multirow{4}{*}{$\begin{array}{l}\text { India's Total merchandise } \\
\text { imports (Million US dollar) }\end{array}$} & Jan-20 & 40107.89 & 41157 & -1049.11 & -2.62 \\
\hline & Feb-20 & 41041.6 & 37478 & 3563.6 & 8.68 \\
\hline & Mar-20 & 41704.75 & 31165 & 10539.75 & 25.27 \\
\hline & Apr-20 & 42525.03 & 17121 & 25404.03 & 59.74 \\
\hline
\end{tabular}


Table 6 Continued

\begin{tabular}{|c|c|c|c|c|c|}
\hline \multirow{4}{*}{$\begin{array}{l}\text { China's Commercial services } \\
\text { exports (Million US dollar) }\end{array}$} & Jan-20 & 25253.9 & & & 0 \\
\hline & Feb-20 & 25448.23 & 39519 & -14070.77 & -55.29 \\
\hline & Mar-20 & 25642.56 & 24104 & 1538.56 & 6.00 \\
\hline & Apr-20 & 25836.89 & 22805 & 3031.89 & 11.73 \\
\hline \multirow{4}{*}{$\begin{array}{l}\text { India’s Commercial services } \\
\text { exports (Million US dollar) }\end{array}$} & Jan-20 & 19036.97 & 18985 & 51.97 & 0.27 \\
\hline & Feb-20 & 19175.53 & 17725 & 1450.53 & 7.56 \\
\hline & Mar-20 & 19314.1 & 18163 & 1151.1 & 5.96 \\
\hline & Apr-20 & 19452.66 & 16450 & 3002.66 & 15.44 \\
\hline \multirow{4}{*}{$\begin{array}{l}\text { China's Commercial services } \\
\text { imports (Million US dollar) }\end{array}$} & Jan-20 & 55422 & & & 0 \\
\hline & Feb-20 & 64033 & 66840 & -2807 & -4.38 \\
\hline & Mar-20 & 72644 & 34566 & 38078 & 52.42 \\
\hline & Apr-20 & 81255 & 28323 & 52932 & 65.14 \\
\hline \multirow{4}{*}{$\begin{array}{l}\text { India’s Commercial services } \\
\text { imports (Million US dollar) }\end{array}$} & Jan-20 & 12054.19 & 12001 & 53.19 & 0.44 \\
\hline & Feb-20 & 12136.91 & 11067 & 1069.91 & 8.82 \\
\hline & Mar-20 & 12219.63 & 11112 & 1107.63 & 9.06 \\
\hline & Apr-20 & 12302.35 & 9301 & 3001.35 & 24.40 \\
\hline
\end{tabular}

Source: Author's Calculation

for all the series. But the actual values for China's merchandise and service trade were not available for the month of January 2020. So the comparison for the month of January has been omitted. The negative deviation shows that the actual performance of imports and exports is better than estimated and positive values shows the counties could not achieve the estimated level of trade performance. As per the results obtained we can see the 


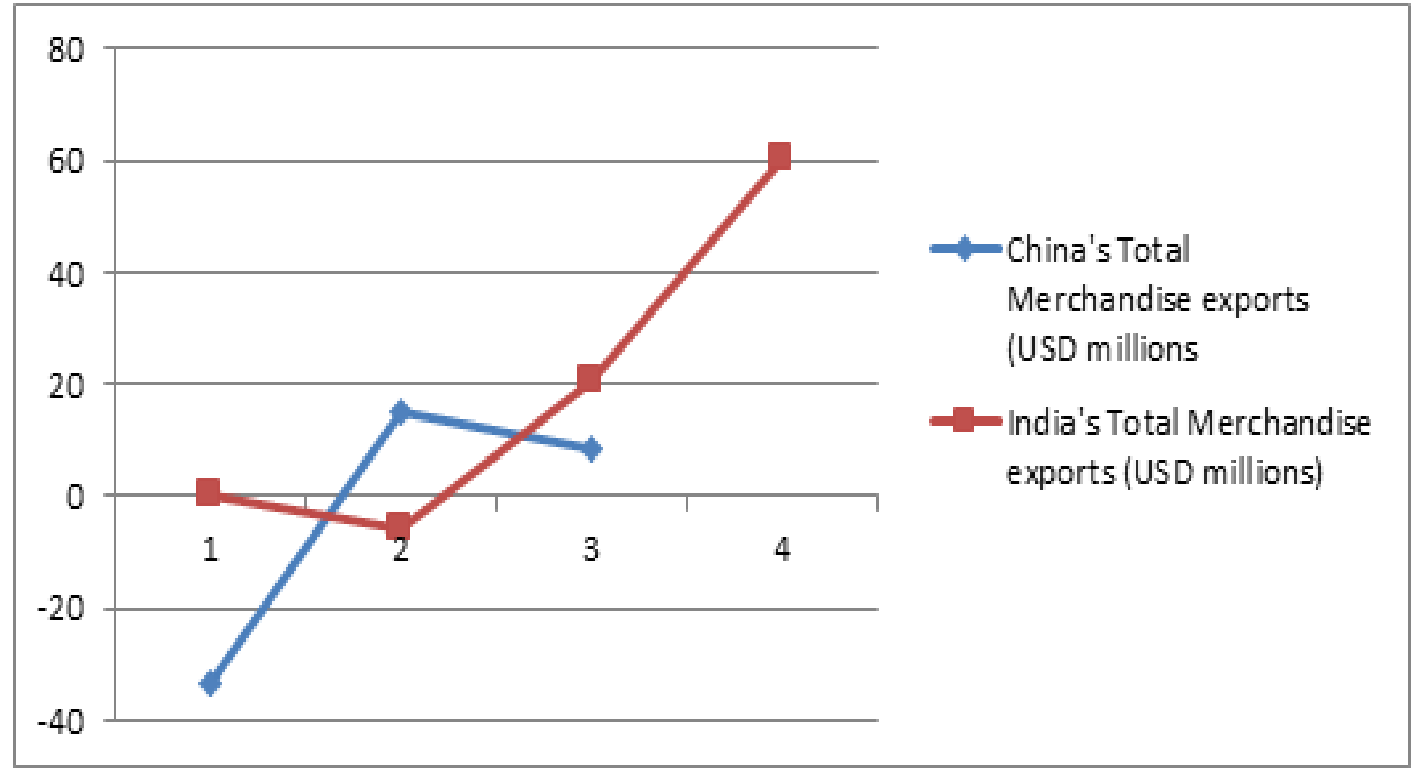

Figure 3. Merchandise exports.

Source: Author

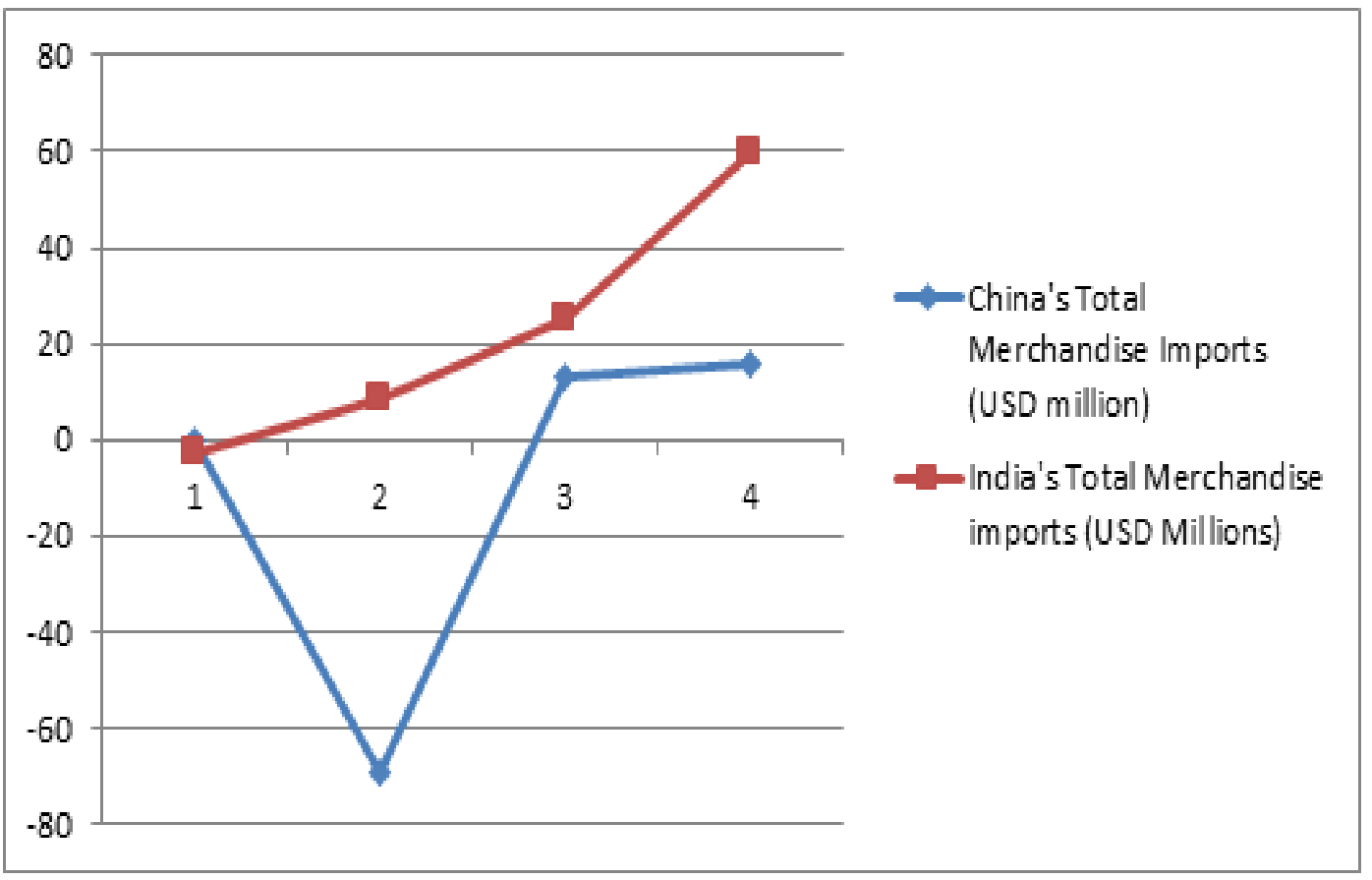

Figure 3.2 Merchandise Imports

Source: Author 


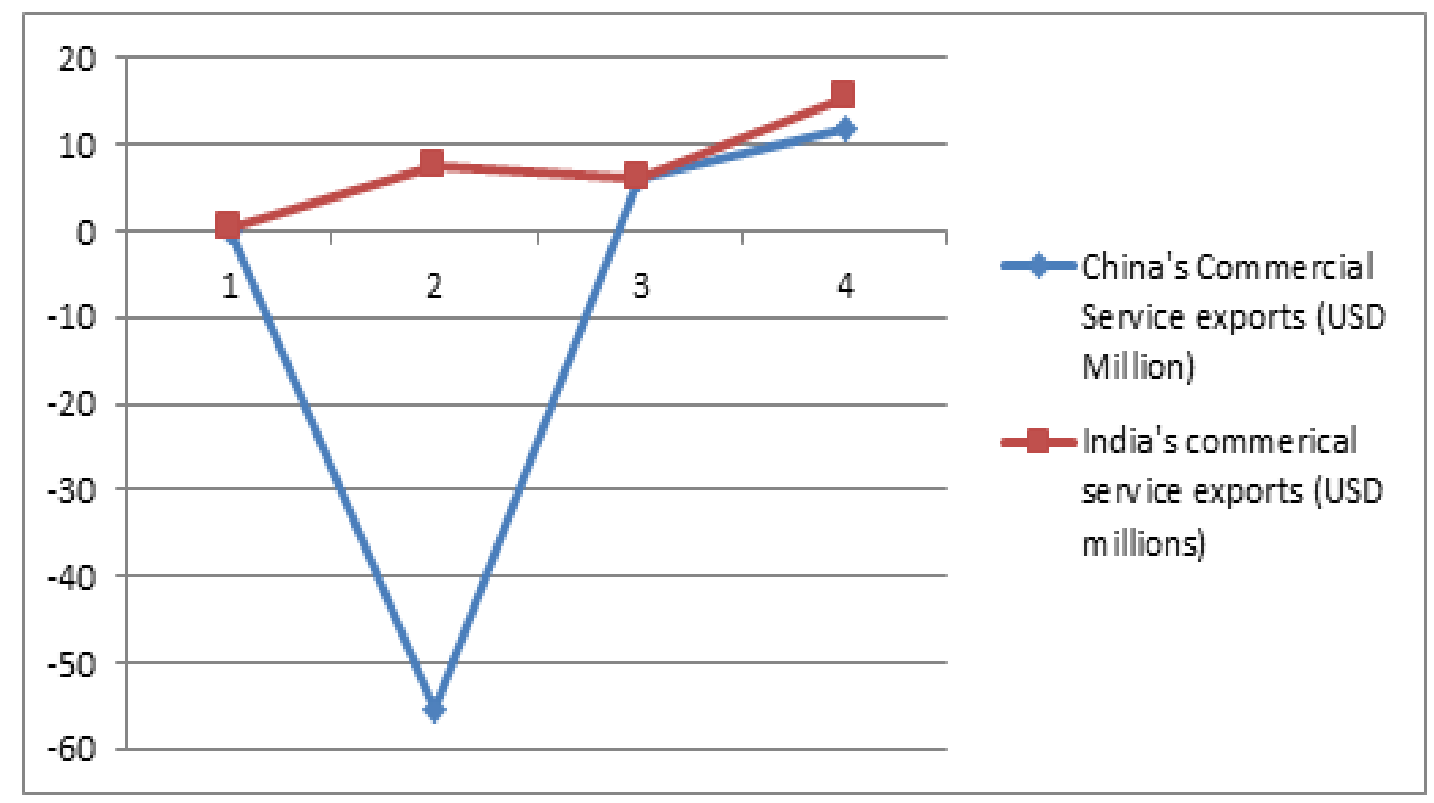

Figure 3.3 Service exports.

Source: Author

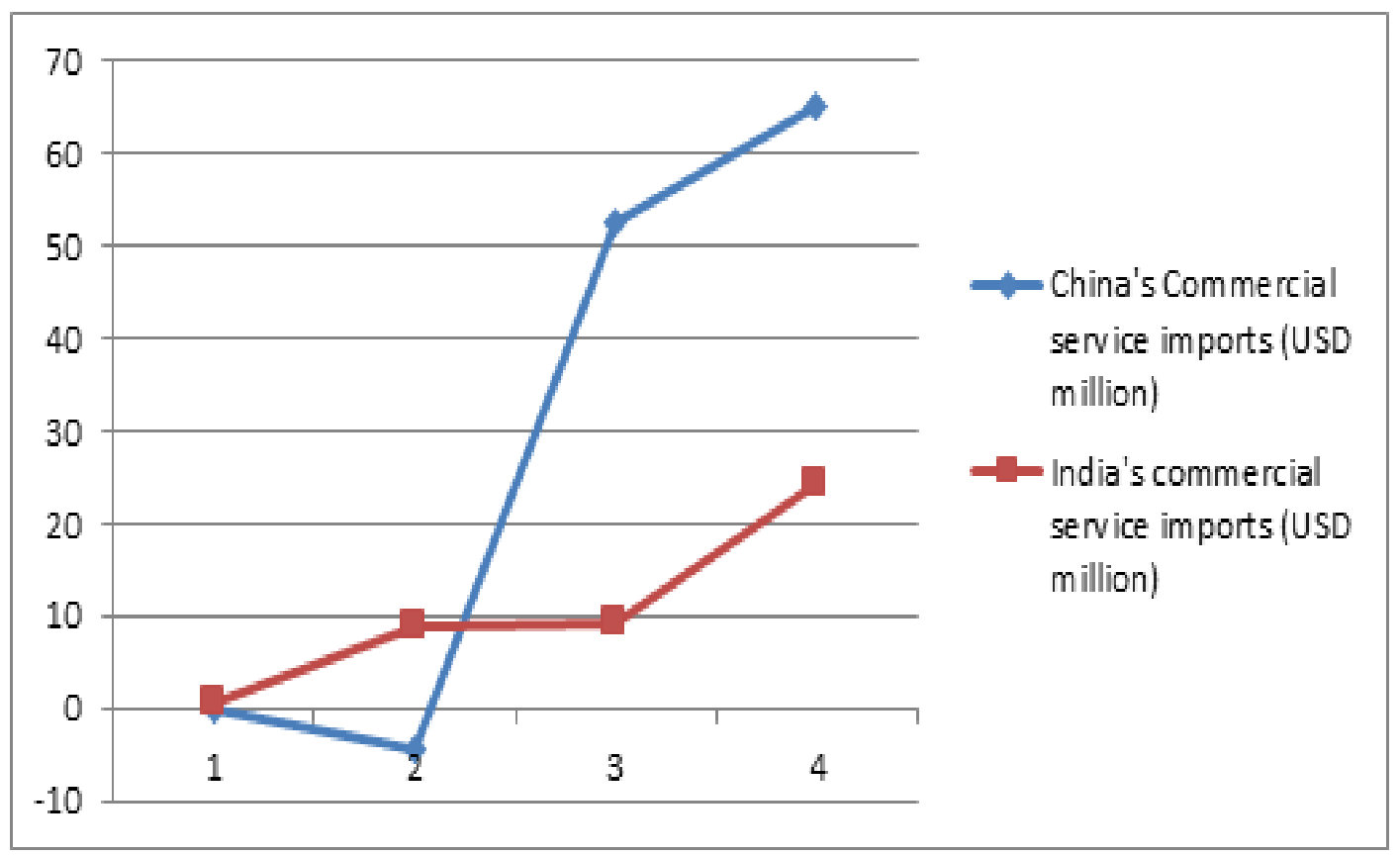

Figure 3.4 Service exports.

Source: Author 
impact of COVID-19 on trade starting from the month of February 2020, since the performance is good in the month of January 2020.

Figures 3.1 to 3.4 show the comparison of India and China's total exports and imports performance for merchandise and service trade. As per Figure 3.1 India is seen in a better position than China in reaching export performance as per estimated. Again Figure 3.2 indicates the better hold of India in comparison to China in case of imports. So we can conclude that India has lost less share of its merchandise trade in comparison to China due to current COVID situations. When we compare service trade (exports and imports) from Figures 3.3 and 3.4 we notice that China is lagging behind from India is case of service exports. India is seen in better position than China in case of service exports. On comparing the service imports deviation of actual from estimated, we notice that China has less deviation. Finally we can conclude that China is more impacted in comparison to India in international trade due to current pandemic.

\section{Threats to Validity}

Current study is limited to merchandise and service trade of India and China with rest of the world. The analysis is restricted to a particular time frame and comparison was made only for the pandemic era. The contrast for that month could not be made due to the non-availability of data for the month of January (China's goods and service imports and export data).

\section{Conclusion and Future Research Direction}

Whilst some of the short-term consequences of the COVID-19 pandemic for international trade are important, they do not appear to be uncontrollable. The current study successfully creates the ARIMA models of times series' of International trade of India and China. The current study undertakes the comparison of adverse impact of COVID-19 on international of India and China. As per the results obtained we can conclude that China is running behind India in achieving exports volume as per its previous years' performance while India's deviation between estimated and actual is comparatively lesser. When we compare imports it can be noticed that
China's deviation is much higher from India. India has been achieving almost estimated imports volume. Thus India has been less hurt by current pandemic in achieving its international merchandise trade performance when compared to China. In case of service trade, India has been in a better position in service exports while China is ahead India in service imports. The current study can be taken further to compare the estimated and actual trade performance when we get actual trade data for coming months.

There is ample scope for researching foreign trade in various (underdeveloped, emerging and developed) world economies. Comparison spectrum can offer a more complex area for comparison during the pandemic phase and can be contrasted with its after-effects too. Studies for comparing India's and China's success can be extended as per data availability.

\section{References}

1. Ahmad, I., Kunroo, M. H. \& Sofi, I. A. (2018). An RCA analysis of India-China Trade Integration: Present, Potential and Prospects. Foreign Trade Review, 53(1), 49-58. https:// doi.org/10.1177/0015732516681885.

2. Alon, I. (2020). COVID-19 and International Business: A Viewpoint. FIIB Business Review. https://doi. org/10.1177/2319714520923579.

3. Baldwin, R. \& Tomiura, E. (2020). Thinking ahead about the trade impact of COVID-19. Economics in the Time of COVID-19, 59.

4. Bell, D., Roberton, S. \& Hunter, P. R. (2004). Animal origins of SARS Corona virus: Possible links with the international trade in small carnivores. Philosophical Transactions of the Royal Society of London. Series B: Biological Sciences, 359(1447), 1107-1114. PMid: 15306396 PMCid: PMC1693393. https://doi.org/10.1098/rstb.2004.1492.

5. Brooks, C. (2002). Introductory Econometrics for Finance. Cambridge University Press.

6. Dhinakaran, D. D. \& Kesavan, N. (2020). Exports and imports stagnation in India during COVID-19 - A Review. GIS Business (ISSN: 1430-3663), 15.

7. Khan, M. A. \& Ahmad, I. (2017). An analysis of export pattern and competitiveness of India-China in Global and Bilateral Market. FIIB Business Review, 6(2), 9-18. https:// doi.org/10.1177/2455265820170202.

8. Mandal, M. \& Mandal, S. (2020). COVID-19 pandemic scenario in India compared to China and rest of the world: 
A data driven and model analysis. medRxiv. https://doi.org /10.1101/2020.04.20.20072744.

9. Pal, P. (2020). The Corona virus crisis and International Trade. COVID-19, 83.

10. Pradhan, J. P. (2017). Emerging multinationals: A comparison of Chinese and Indian outward foreign direct investment. Institutions and Economies, 113-148.

11. Vidya, C. \& Prabheesh, K. (2020). Implications of COVID19 pandemic on the global trade networks. Merging
Markets Finance and Trade, 56(10), 2408-2421. https://doi. org/10.1080/1540496X.2020.1785426.

12. Zhao, Y., Liu, Y., Qiao, X., Wang, S., Zhang, Z., Zhang, Y., et al. (2018). Tracing value added in gross exports of China: Comparison with the USA, Japan, Korea and India based on generalized LMDI. China Economic Review, 49, 24-44. https://doi.org/10.1016/j.chieco.2017.12.010. 